\title{
Drip irrigation system powered by photovoltaic panels
}

\author{
Soni Willian Haupenthal
}

State University of Western Parana, Parana, Brazil

Corresponding author, e-mail: soniwillian@hotmail.com

\begin{abstract}
The objective of this work was to evaluate the performance of a drip irrigation system with photovoltaic energy without the use of energy storage system. The experiment was conducted at the State University of the West Parana - UNIOESTE, Campus of Cascavel, in the laboratory CASA project, during six days, analyzing the coefficients of uniformity of Christiansen (CUC), coefficient of uniformity of distribution (CUD) for measurement of 16 drippers by sector (Keller method) and later the coefficient of variation (CV). In the energy part, the irradiance and the current generated by the panel were analyzed. The irrigation set was also classified according to the ASABE standard. The statistical quality control of the system was also performed in order to evaluate the quality of the set considered, with the means being compared by the Tukey test at $5 \%$. The coefficients of each treatment reached an excellent level according to their classifications. The main results allowed to evaluate that the flow control by dripper showed a significant effect for the factors analyzed. The system obtained excellent processability according to the analyzes of distribution uniformities. It was also concluded that there was a significant relationship between the coefficients (CUC, CUD and CV) with the process capacity of the flow data.
\end{abstract}

Keywords: Distribution uniformity, localized irrigation, photovoltaic energy

\section{Introduction}

The increase in need for water resources to serve all sectors, whether human, industrial or even agricultural in the irrigation sector, boosts research aiming at a qualitative and rational use (Silva et al., 2013).

Furthermore, increasing population requires increasing amounts of water and promotes promoting water competition between agriculture and other sectors of the economy (Alves et al., 2015). Thus, farmers are forced to consider more carefully the adoption of strategies for minimizing consumption (Costa et al., 2007).

Of the large users of water resources, irrigation is the segment that consumes the most water. In some regions, water consumption through irrigation can exceed $70 \%$ of the total amount used (Dalri et al., 2015).

Among the more usual systems, sprinkler irrigation usually presents lower uniformity of water distribution, application efficiency and water productivity when compared to the localized irrigation method (Benício et al., 2009; Paulinho et al., 2009; Doun et al., 2013).

In order to demonstrate the importance of irrigation management, the efficiency rates of the system have been proposed. The efficiency of water use is defined as the ratio between the dry matter rate of a crop and its transpiration rate (Frederiksen \& Allen, 2011; Gleick et al., 2011). 
Objectifying to rationalize the water used in irrigation, an ideal system operation is fundamental, with an assessment of the difference in the water volumes applied by the emitters along the lateral line (Nascimento et al., 2009).

With the intention to reduce the amount of water consumed in irrigation, the drip system is one of the most suitable options, thanks to its high efficiency and lower water use rates compared to other irrigation processes. According to Mantovani (2012), this concept is crucial to avoid the waste of an asset that, in addition to being fundamental to life, is increasingly insufficient

Already the choice of power supplier, the photovoltaic panel, has a priority be a source clean, renewable energy source, easy to install and available to away places (López-Mata et al., 2010).

Once the energy use has become more and more present in the daily lives of people and is brought about by the presence of new technologies and population growth (Mavad et al., 2017), and with the awareness that many countries use large-scale fossil fuels for the production of electricity, we aspire to reduce the emission of polluting gases, as stated in the Kyoto protocol, which addresses the need to use new sources of energy, such as photovoltaics (Kalogirou, 2009).

One of the benefits of energy generation from the sun is accessibility in remote places, where the costs of implementing a conventional network are unfeasible, in the case of numerous rural properties (Martins and Pereira, 2011), thus contributing to the social, economic and universal development of access to energy.
Therefore, the present study had the objective of evaluating a drip irrigation system with photovoltaic energy connected directly to the pumping system. Realizing the collect of the drippers by the method of Keller and Karmelli (1975). Evaluating the irrigation system with the photovoltaic energy system from the determination of CUC and CUD.

\section{Materials and methods}

The project was developed at the State University of Western of Paraná (Unioeste),

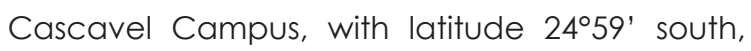
longitude $53^{\circ} 23^{\prime}$ west and an altitude of 750 meters.

The municipality of Cascavel is located in the western region of the State of Paraná and, according to the Sundata Program, has an annual average irradiance of $4.95 \mathrm{kWh} \mathrm{m}^{-2}$ day $^{-1}$ (Sundata, 2017).

Because the sun is one of the daily sources of renewable energy, the values of solar irradiance for the city of Cascavel make it a suitable place for the use of this form of energy.

Since Brazil, due to its privileged location, possesses adequate values of averages of solar irradiance throughout its territory. Since its indices for any national region are larger than most European countries, where photovoltaic energy system projects have a much greater appeal (Martins et al., 2012).

The drippers used in the test were supplied by Naandanjain Irrigation, model Topdrip Pc \& PC As, with $0.3 \mathrm{~m}$ of space between the drippers. The technical characteristics of the drip tube are shown in Table 1.

Table 1. Technical characteristics of the Dripper

\begin{tabular}{ll}
\hline Flow coefficient & $0.0011,0.0016,0.002,0.0022 \mathrm{~m}^{3} \mathrm{~h}^{-1}$ \\
Pressure regulation & $40-300 \mathrm{kPa}$ \\
Pressure regulation & $40-300 \mathrm{kPa}$, according to wall thickness \\
Pressure regulation & $13-25 \mathrm{mil}, 0.33-0.63 \mathrm{~mm}$ \\
Recommended filtering & 130 microns \\
\hline
\end{tabular}

In order to supply electricity to the maintaining the voltage as close as possible to pumping system, three photovoltaic modules, model KS50, SOLARTEC, brand, duly directed to the true north, were connected in parallel $12 \mathrm{~V}$ in direct current in the water pump. Table 2 shows the technical characteristics of the photovoltaic module. 
For water pumping, a SHURFLO diaphragm pump, model 8000 with a maximum flow rate of $0.49 \mathrm{~m}^{3} \mathrm{~h}^{-1}$ and a manometric capacity of $207 \mathrm{kPa}$, was used, and the water was available in a $0.1 \mathrm{~m}^{3}$ water tank. Table 3 below presents the technical information of the diaphragm pump.

Table 2. Technical characteristics of the Photovoltaic Module

\begin{tabular}{ll}
\hline Rated power (RP) & $50 \mathrm{~W}$ \\
Current at RP & $3 \mathrm{~A}$ \\
Voltage at RP & $16.7 \mathrm{~V}$ \\
Open circuit voltage & $21.5 \mathrm{~V}$ \\
Short circuit current & $3.10 \mathrm{~A}$ \\
Maximum system voltage & $600 \mathrm{~V}$ \\
Dimensions & $1280 \times 343 \times 36 \mathrm{~mm}$ \\
Weight & $6.5 \mathrm{~kg}$ \\
\hline
\end{tabular}

Table 3. Technical characteristics of the Hydraulic Diaphragm Pump

\begin{tabular}{ll}
\hline Supply voltage & $12 \mathrm{~V}$ \\
Maximum setback height & $42 \mathrm{~m}$ \\
Connection & $1 / 2 "$ \\
Tube diameter & $1 / 2 "$ at $1 "$ \\
Dimensions & $215 \times 114 \times 104 \mathrm{~mm}$ \\
Weight & $2.1 \mathrm{~kg}$ \\
Flow & $490 \mathrm{~L} \mathrm{~h}-1$ (without setback) \\
Manometric Head & $21.09 \mathrm{mwc}$ \\
\hline
\end{tabular}

To measure the electricity supplied by the photovoltaic system to the water pump, two multimeters of the INSTRUTHERM brand were used.

One of the multimeters was connected in parallel with the output terminals of the photovoltaic panel for the measurement of the electric voltage in direct current, and the other multimeter connected in series to the hydraulic pump for the current measurement consumed by the load, while the solar radiation data were collected using the MES-100 solar energy meter with a scale of up to $2000 \mathrm{~W} \mathrm{~m}^{-2}$.

The irrigation system was arranged parallel to the ground inside the CASA project and, therefore, the experiment is characterized as indoor, without the interference of weather variations, the drip tubes being supported by cables. A reservoir with a capacity of $0.1 \mathrm{~m}^{3}$ was installed to supply the system and the photovoltaic panels in the vicinity of CASA to supply the power requirement of the diaphragm pump.

At the outlet of the tank, a screen-type filter included in the kit was installed. A main line with a gap of $3.10 \mathrm{~m}$ was connected after the filter. On the main line, four lateral lines were connected, with a space of $0.40 \mathrm{~m}$ between them. Each lateral line is composed of a drip tube, and it contains 18 inline drippers, spaced every $0.30 \mathrm{~m}$, as shown in Figure 1.

Small-scale irrigation brings some benefits because it deals with simpler installation systems, therefore, a lower installation cost and greater efficiency, while generating savings in exploited water resources (Dillon, 2011).

Already the photovoltaic energy supply has a number of economics benefits, in view of the considerable residential consumption of electricity energy (Naspolini et al., 2010), among other consumptions that can be supplied by the system. Emphasizing that solar energy has renewable and ecological characteristics affirmed by Oliveira et al. (2008),

According to Keller and Karmeli (1975), the data collection methodology requires 4 collection points in each line, located in the first lateral line dripper, a dripper at 1/3 of the total length of the lateral line, a dripper at $2 / 3$ of the length, and the last dripper, totaling 16 collection points.

The selected lateral lines follow the criterion of the 1 st, 1/3,2/3 and last dripper; however, since the experiment has only four lines, 
this criterion was ruled out.

For the collection of the water volume, the methodology recommended was followed. All collectors were positioned at the same time at the collection points while the system was in operation (Figure 2). For this experiment, a collection time of 5 minutes was determined after the end of the time, all were removed at the same time, and the volume of water of each collector was measured.

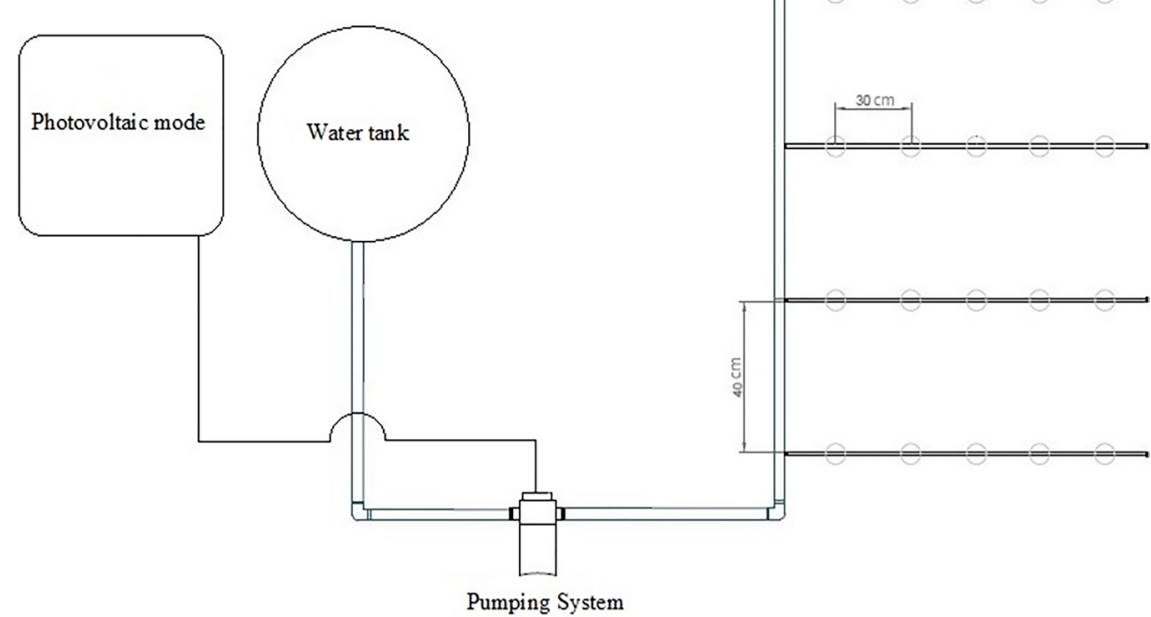

Figure 1. Layout of the drip irrigation system with photovoltaic energy

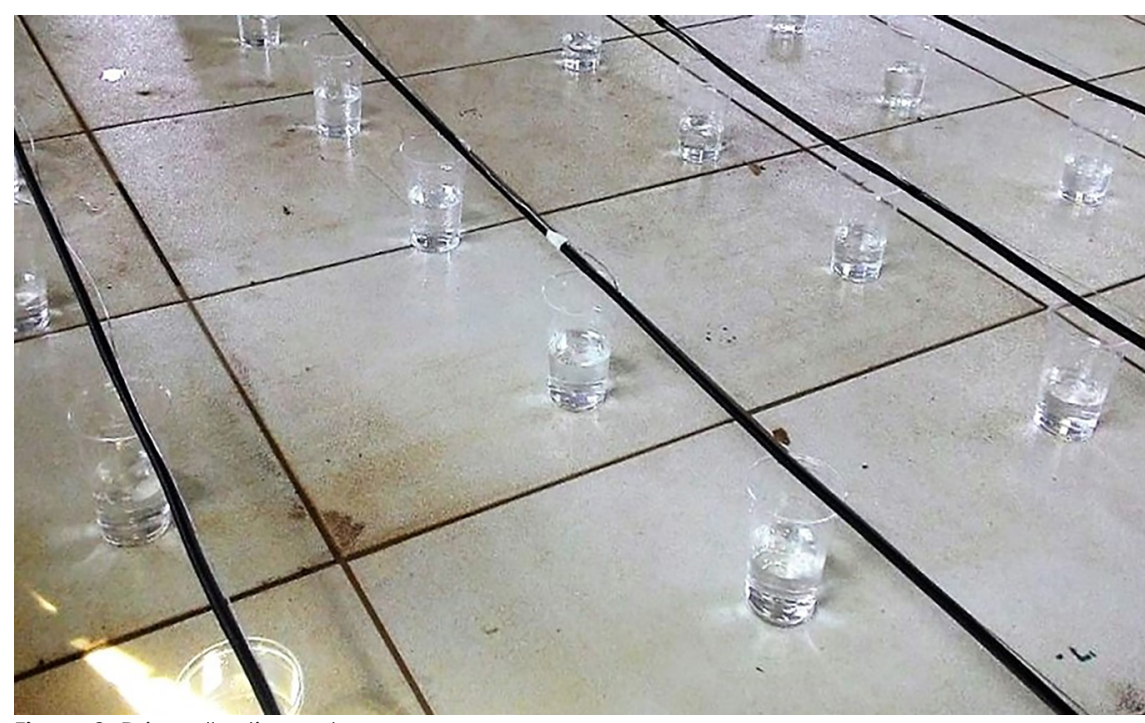

Figure 2. Drip collection system

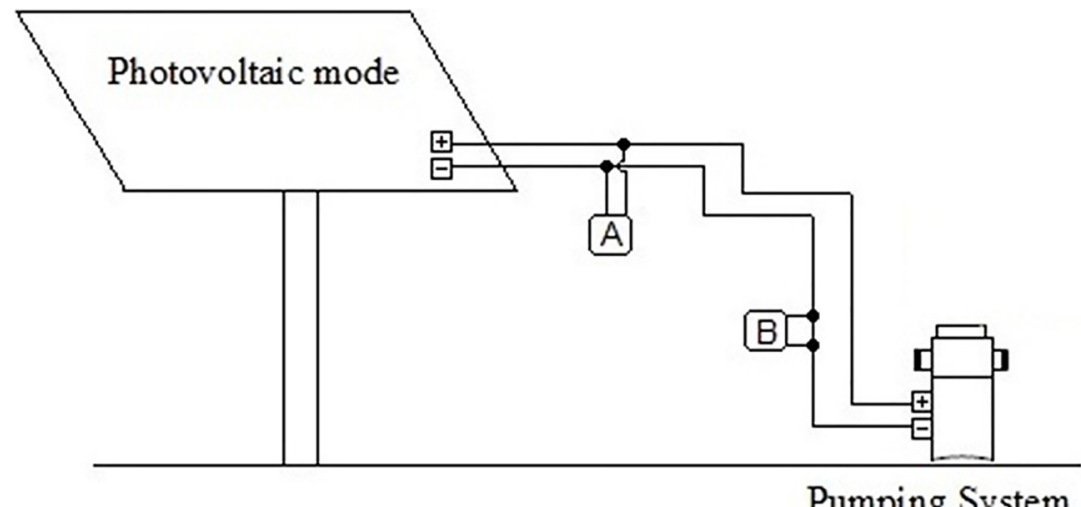

Figure 3. Layout of the system current and voltage collection system, (A) Multimeter connected in parallel for voltage measurement, (B) Multimeter connected in series for current measurement. 
The voltage and electric current in the pumping system were measured at the same time as the dripper tests during the water collection period in the collectors, as shown in Figure 3.

The water comes from a water box with a capacity of $0.1 \mathrm{~m}^{3}$, placed outside the CASA project at the ground level. The operation is managed by photovoltaic panels connected directly to the water pump for the purposes of ensuring the power supply.

The water is then pumped from the hydraulic pump hoses to the dripper located inside the CASA project, and the uniformity coefficients of the drippers are then determined.

While the data from the drippers is collected, the solar radiation levels are then determined, as well as ambient temperature and electric current during the operation of the pump.

The criteria for assessing the uniformity of water application in the system were the coefficient of variation (CV) of the lateral line emitter, the distribution uniformity coefficient (DUC), and Christiansen's uniformity coefficient (CUC).

\section{Christiansen's uniformity coefficient} (CUC), proposed by Christiansen (1942), is one of the most widely used methods, as it adopts the absolute mean deviation as a measure of dispersion, as can be observed in Equation 01.

Where:

$$
C U C=100\left\{1-\frac{\sum_{i=1}^{n}\left|x_{i}-x_{\text {med }}\right|}{n-x_{\text {med }}}\right\}
$$

CUC: Christiansen's Uniformity Coefficient (\%); $\mathrm{X}_{\mathrm{i}}$ : flow of each dripper $\left(\mathrm{m}^{3} \mathrm{~h}^{-1}\right)$; $\mathrm{X}_{\text {med }}$ : mean flow of the drippers $\left(\mathrm{m}^{3} \mathrm{~h}^{-1}\right)$; and $\mathrm{n}$ : number of drippers.

The distribution uniformity coefficient (DUC) is defined as the water distribution measure that relates the fourth part of the total area and receives less water with the average level applied if the entire area receives at least the required actual level. A low DUC value indicates excessive percolation loss, which can be observed in Equation 02.

$$
D U C=100\left(\frac{x_{25}}{x_{\text {med }}}\right)
$$

Where:

DUC: distribution uniformity coefficient $(\%) ; \mathrm{X}_{25}$ : mean value of $25 \%$ of the lowest flows $\left(\mathrm{m}^{3} \mathrm{~h}^{-1}\right)$; $\mathrm{X}_{\text {med }}$ : Means of all flows $\left(\mathrm{m}^{3} \mathrm{~h}^{-1}\right)$.

Table 4. Criteria for CUC and DUC classification, according to Asabe (1996)

\begin{tabular}{ccc}
\hline Classification & CUC & DUC \\
\hline Excellent & $>90$ & $>90$ \\
Good & $80-90$ & $80-90$ \\
Regular & $70-80$ & $70-80$ \\
Bad & $60-70$ & $60-70$ \\
Unacceptable & $<60$ & $<60$ \\
\hline
\end{tabular}

The Asabe standard (1996) presents in Table 4 the recommended classification for the distribution uniformity coefficient values.

Another important parameter in localized irrigation is the coefficient of variation (CV), proposed by Keller \& Bliesner (1990) and presented in Equation 03. This parameter is evaluated, as the emitters have small dimensions that hinder precision in their manufacture. The variations in flow rates, caused by constructive failures, present normal distribution; thus, the use of statistical concepts corresponding to this distribution for quantitative conclusions is permitted.

$$
C V=\frac{s}{x_{\text {med }}} \cdot 100
$$

Where:
CV: Coefficient of variation (\%); s: standard deviation $\left(\mathrm{m}^{3} \mathrm{~h}^{-1}\right) ; \mathrm{X}_{\text {med }}$ : means of all flows $\left(\mathrm{m}^{3} \mathrm{~h}^{-1}\right)$.

In order for drippers to be classified into quality categories, the coefficient of variation (CV) is used. Thus, the emitters are classified according to Table 5.

Statistical analysis was performed for the statistical test, with data considered normal, not requiring transformation, as well as the comparison of means by the Tukey test at $5 \%$ of significance, calculated by the SISVAR software program, version 5.3, developed by Ferreira (2008).

\section{Results and Discussion}

The results presented in Table 6 refer to 
Table 5. Coefficient of variation (CV) of the emitters

\begin{tabular}{lcl}
\hline Type of emitter & CV $(\%)$ & Interpretation \\
\hline & $<5$ & Excellent \\
Emitters with & 5 a 7 & Average \\
rated output & 7 a 11 & Marginal \\
& 11 a 15 & Poor \\
& $>15$ & Unacceptable \\
\hline
\end{tabular}

Table 6. Results of the means of the collections

\begin{tabular}{lllllll}
\hline Variables & 1st Day & 2nd Day & 3rd Day & 4th Day & 5th Day & 6th Day \\
\hline Mean irradiance $\left(\mathrm{W} \mathrm{m}^{-2}\right)$ & 618.00 & 893.80 & 888.60 & 811.17 & 979.67 & 914.80 \\
Voltage $(\mathrm{V})$ & 19.52 & 19.73 & 19.78 & 19.00 & 19.60 & 19.37 \\
Current $(\mathrm{A})$ & 2.88 & 3.12 & 3.14 & 2.97 & 3.23 & 3.02 \\
Temperature ( ${ }^{\circ} \mathrm{C}$ ) & 20.52 & 22.46 & 22.40 & 25.11 & 28.70 & 28.22 \\
Average CUC (\%) & 98.75 & 99.13 & 99.09 & 98.77 & 98.78 & 99.01 \\
Average DUC (\%) & 97.91 & 98.62 & 98.945 & 97.61 & 98.45 & 98.50 \\
\hline
\end{tabular}

the means of solar radiation, voltage supplied by the panels, current, at the average temperature in the days of collection, as well as the CUC and DUC, each test relating to the water volume collection of 16 points of the system (Keller \& Karmeli, 1975).

When the mean values of Christiansen's uniformity coefficient (CUC) of Table 6 are analyzed, it is noted that in all treatments, the values are considered acceptable, all values equal to or greater than $90 \%$ being considered acceptable (Asabe, 1996).

In a research in which a drip tube was used, for a period of 1620 hour, Puig-Bargués et al. (2010) found an average distribution uniformity of $90 \%$ with self-compensating emitter, however, at the end of each irrigation period, the emitters were washed

It is observed that the minimum value allowed is $70 \%$, that is, based on the two criteria, the CUC values are excellent in all applied treatments (Bernardo et al., 2005). However, the fifth day of collection which occurs the highest value of solar irradiance presented a value of $98.78 \%$ not representing the highest value of the coefficient of uniformity of Christiansen. It was also observed that the standard deviations were low, that is, there was little variation of the obtained data.

The average of CUC reached $98.92 \%$ and can therefore be considered excellent, since the uniformity of water distribution in irrigated areas directly influences the management, quality, efficiency and cost of irrigation, as well as the development of the crop in the field.

The results are also based on the DUC values, where a mean value of $98.38 \%$ was reached and the distribution coefficient is considered excellent in values greater than 90\% (Asabe, 1996). The minimum value accepted is $80 \%$, i.e., based on the criteria evaluated, the CUC and DUC values have excellent values with averages above $98 \%$ (Bernardo et al., 2005).

The results presented in Table 7 refer to the mean flow rates per test, coefficient of variation, standard deviation, and maximum and minimum flows.

It was observed that in all treatments showed a similar behavior, with little variability, with respect to the standard deviation. This can be proven by CV values below $5 \%$, indicating homogeneous data.

Tabela 7. Analise estatística da irrigação por gotejamento

\begin{tabular}{cccccc}
\hline & Mean $\mathrm{m}^{3} \mathrm{~h}^{-1}$ & $\mathrm{CV}$ & $\mathrm{SD}$ & Max. $\mathrm{m}^{3} \mathrm{~h}^{-1}$ & Min. $\mathrm{m}^{3} \mathrm{~h}^{-1}$ \\
\hline 1st Day & 0.00356 & 1.3697 & 0.0486 & 0.00366 & 0.00342 \\
2nd Day & 0.0063 & 1.0383 & 0.0387 & 0.00384 & 0.00354 \\
3rd Day & 0.003711 & 1.1325 & 0.0421 & 0.00384 & 0.00354 \\
4th Day & 0.00362 & 1.44 & 0.0607 & 0.00373 & 0.00336 \\
5th Day & 0.00388 & 1.29 & 0.0455 & 0.00390 & 0.00348 \\
6th Day & 0.00369 & 1.30 & 0.0458 & 0.00376 & 0.00346 \\
\hline CV: coefficient of variation (\%); SD: standard deviation; Max: Maximum; Min: Minimum.
\end{tabular}


In order to consider a data as acceptable, the emitter would be required to have a coefficient of variation less than $15 \%$. In the analysis of the data in Table 7, the treatments used were acceptable and considered as excellent, with 95\% confidence (Asabe, 1996).

Table 8 shows the highest CUC values, which are considered essential for quality irrigation to occur, with a percentage close to

Table 8. Measurement of drippers within 5 minutes

\begin{tabular}{|c|c|c|c|c|}
\hline \multirow{2}{*}{ DRIPPER } & \multicolumn{4}{|c|}{ LINES } \\
\hline & 1 & 2 & 3 & 4 \\
\hline 1 & $0.00372 \mathrm{~b}$ & $0.00372 \mathrm{~b}$ & $0.00372 \mathrm{~b}$ & $0.00372 \mathrm{~b}$ \\
\hline 2 & $0.00372 \mathrm{~b}$ & $0.00372 \mathrm{~b}$ & $0.00372 \mathrm{~b}$ & $0.00372 \mathrm{~b}$ \\
\hline 3 & $0.00372 \mathrm{~b}$ & $0.00372 \mathrm{~b}$ & 0.00372 b & $0.00372 b$ \\
\hline 4 & $0.00372 \mathrm{~b}$ & $0.00372 b$ & $0.00372 b$ & $0.00372 b$ \\
\hline 5 & $0.00372 \mathrm{~b}$ & $0.00372 b$ & $0.00378 c$ & $0.00372 \mathrm{~b}$ \\
\hline 6 & $0.00372 \mathrm{~b}$ & $0.00372 \mathrm{~b}$ & $0.00378 \mathrm{c}$ & $0.00378 \mathrm{c}$ \\
\hline 7 & $0.00366 a$ & $0.00372 \mathrm{~b}$ & $0.00372 \mathrm{~b}$ & $0.00378 \mathrm{c}$ \\
\hline 8 & $0.00372 \mathrm{~b}$ & $0.00372 \mathrm{~b}$ & $0.00372 \mathrm{~b}$ & $0.00366 \mathrm{c}$ \\
\hline 9 & $0.00372 \mathrm{~b}$ & $0.00378 \mathrm{c}$ & $0.00372 \mathrm{~b}$ & $0.00372 \mathrm{~b}$ \\
\hline 10 & $0.00372 \mathrm{~b}$ & $0.00372 b$ & $0.00372 \mathrm{~b}$ & $0.00372 \mathrm{~b}$ \\
\hline 11 & $0.00372 b$ & $0.00372 \mathrm{~b}$ & $0.00366 a$ & $0.00372 \mathrm{~b}$ \\
\hline 12 & $0.00372 \mathrm{~b}$ & $0.00372 \mathrm{~b}$ & $0.00372 \mathrm{~b}$ & $0.00372 \mathrm{~b}$ \\
\hline 13 & $0.00372 \mathrm{~b}$ & $0.00372 \mathrm{~b}$ & $0.00372 \mathrm{~b}$ & $0.00372 \mathrm{~b}$ \\
\hline 14 & $0.00366 a$ & $0.00372 \mathrm{~b}$ & $0.00378 \mathrm{c}$ & $0.00372 \mathrm{~b}$ \\
\hline 15 & $0.00372 \mathrm{~b}$ & $0.00372 \mathrm{~b}$ & $0.00372 \mathrm{~b}$ & $0.00372 \mathrm{~b}$ \\
\hline 16 & $0.00366 a$ & $0.00372 \mathrm{~b}$ & $0.00366 a$ & $0.00372 \mathrm{~b}$ \\
\hline 17 & $0.00366 a$ & $0.00372 \mathrm{~b}$ & $0.00372 \mathrm{~b}$ & $0.00372 \mathrm{~b}$ \\
\hline 18 & $0.00366 a$ & $0.00372 \mathrm{~b}$ & $0.00366 a$ & $0.00366 a$ \\
\hline
\end{tabular}

Table 9. Mean values of CUC, DUC, SD, CV, mean of the drippers, voltage, and current

\begin{tabular}{cc}
\hline CUC & $99.43 \%$ \\
DUC & $98.87 \%$ \\
SD & 0.028 \\
CV & $0.761 \%$ \\
Mean & $0.00371 \mathrm{~m}^{3} \mathrm{~h}^{-1}$ \\
Voltage & $19.6 \mathrm{~V}$ \\
Current & $3.1 \mathrm{~A}$ \\
\hline Where: CUC: Christiansen's Uniformity Coefficient (\%); CUD: Distribution Uniformity \\
Coefficient (\%); SD: : standard deviation; CV: coefficient of variation (\%); Mean, $\mathrm{m}^{3} \mathrm{~h}^{-1}$; \\
Voltage (V): Current (A).
\end{tabular}

Christiansen's Uniformity Coefficient (CUC), Distribution Uniformity Coefficient (DUC), standard deviation (SD), coefficient of variation $(\mathrm{CV})$, mean and current of the photovoltaic panel for the suction pump are presented in the table below.

Table 10 presents the data for the third collection of May 21, at 11:00 am, at the time of the collection, with a temperature of 20.4 ${ }^{\circ} \mathrm{C}$ and a solar radiation of $630 \mathrm{~W} \mathrm{~m}^{-2}$, the data so it can be seen that the drippers have a flow distribution at a short distance from a perfect distribution. It also should be highlighted that this 28 , with a temperature of $22.4^{\circ} \mathrm{C}$ and a solar radiation of $889 \mathrm{~W} \mathrm{~m}^{-2}$, one of the highest that found during the data collection.
$100 \%$ and the DUC percentage close to $99 \%$, collection was carried out at 11:00 am on May 
Table 10. Measurement of drippers within 5 minutes

\begin{tabular}{ccccc}
\hline DRIPPER & $\mathbf{1}$ & $\mathbf{2}$ & $\mathbf{3}$ & $\mathbf{4}$ \\
\hline $\mathbf{1}$ & $0.0036 \mathrm{~d}$ & $0.00348 \mathrm{~b}$ & $0.0036 \mathrm{~d}$ & $0.00342 \mathrm{a}$ \\
$\mathbf{2}$ & $0.00366 \mathrm{e}$ & $0.00348 \mathrm{~b}$ & $0.00348 \mathrm{~b}$ & $0.00354 \mathrm{c}$ \\
$\mathbf{3}$ & $0.0036 \mathrm{~d}$ & $0.00348 \mathrm{~b}$ & $0.0036 \mathrm{~d}$ & $0.00366 \mathrm{e}$ \\
$\mathbf{4}$ & $0.0036 \mathrm{~d}$ & $0.0036 \mathrm{~d}$ & $0.0036 \mathrm{~d}$ & $0.0036 \mathrm{~d}$ \\
$\mathbf{5}$ & $0.00348 \mathrm{~b}$ & $0.0036 \mathrm{~d}$ & $0.0036 \mathrm{~d}$ & $0.0036 \mathrm{~d}$ \\
$\mathbf{6}$ & $0.00354 \mathrm{c}$ & $0.0036 \mathrm{~d}$ & $0.0036 \mathrm{~d}$ & 0.00366 \\
$\mathbf{7}$ & $0.0036 \mathrm{~d}$ & $0.0036 \mathrm{~d}$ & $0.0036 \mathrm{~d}$ & $0.0036 \mathrm{~d}$ \\
$\mathbf{8}$ & $0.0036 \mathrm{~d}$ & $0.00354 \mathrm{c}$ & $0.00348 \mathrm{~b}$ & $0.00354 \mathrm{c}$ \\
$\mathbf{9}$ & $0.0036 \mathrm{~d}$ & $0.00348 \mathrm{~b}$ & $0.00354 \mathrm{c}$ & $0.00354 \mathrm{c}$ \\
$\mathbf{1 0}$ & $0.00348 \mathrm{~b}$ & $0.00354 \mathrm{c}$ & $0.00354 \mathrm{c}$ & $0.00354 \mathrm{c}$ \\
$\mathbf{1 1}$ & $0.0036 \mathrm{~d}$ & $0.0036 \mathrm{~d}$ & $0.00354 \mathrm{c}$ & $0.00354 \mathrm{c}$ \\
$\mathbf{1 2}$ & $0.00354 \mathrm{c}$ & $0.0036 \mathrm{~d}$ & $0.00348 \mathrm{~b}$ & $0.0036 \mathrm{~d}$ \\
$\mathbf{1 3}$ & $0.00354 \mathrm{c}$ & $0.0036 \mathrm{~d}$ & $0.00354 \mathrm{c}$ & $0.00366 \mathrm{e}$ \\
$\mathbf{1 4}$ & $0.0036 \mathrm{~d}$ & $0.00354 \mathrm{c}$ & $0.0036 \mathrm{~d}$ & $0.0036 \mathrm{~d}$ \\
$\mathbf{1 5}$ & $0.0036 \mathrm{~d}$ & $0.00348 \mathrm{~b}$ & $0.00354 \mathrm{c}$ & $0.0036 \mathrm{~d}$ \\
$\mathbf{1 6}$ & $0.00354 \mathrm{c}$ & $0.0036 \mathrm{~d}$ & $0.0036 \mathrm{~d}$ & $0.0036 \mathrm{~d}$ \\
$\mathbf{1 7}$ & $0.00354 \mathrm{c}$ & $0.0036 \mathrm{~d}$ & $0.0036 \mathrm{~d}$ & $0.0036 \mathrm{~d}$ \\
$\mathbf{1 8}$ & $0.00354 \mathrm{c}$ & $0.00354 \mathrm{c}$ & $0.00348 \mathrm{~b}$ & $0.00354 \mathrm{c}$ \\
\hline
\end{tabular}

Table 11. Mean values of CUC, DUC, SD, CV, mean of the drippers, voltage, and current

\begin{tabular}{cc}
\hline CUC & $98.54 \%$ \\
DUC & $97.19 \%$ \\
SD & 0.052 \\
CV & $1.460 \%$ \\
Mean & $0.00356 \mathrm{~m}^{3} \mathrm{~h}^{-1}$ \\
Voltage & $19.6 \mathrm{~V}$ \\
Current & $2.9 \mathrm{~A}$ \\
\hline Where: CUC: Christiansen's Uniformity Coefficient (\%); CUD: Distribution Uniformity Coefficient (\%); \\
SD: standard deviation; CV: coefficient of variation (\%); Mean, $\mathrm{m}^{3} \mathrm{~h}^{-1}$; Voltage (V); Current (A).
\end{tabular}

(SD), coefficient of variation (CV), mean and current values of the photovoltaic panel for the suction pump are presented in the table below.

Comparing with the data from the first day of collection for the fifth day, it is possible to observe an increase in the values of the mean solar radiation, from $618.00 \mathrm{~W} \mathrm{~m}^{-2}$ on the first day to $979.67 \mathrm{~W} \mathrm{~m}^{-2}$ on the fifth day of collection, with an increase of $361.67 \mathrm{~W} \mathrm{~m}^{-2}$, which subsequently increased by $0.3 \vee$ the mean voltage available from the photovoltaic panel to the water pump, which recorded a small increase in the average flow rate of the drippers going from $0.00356 \mathrm{~m}^{3}$ $\mathrm{h}^{-1}$ to $0.00388 \mathrm{~m}^{3} \mathrm{~h}^{-1}$, with an increase of 0.00032 $\mathrm{m}^{3} \mathrm{~h}^{-1}$.

Compared to other data collection days, close values were reached in all the evaluated questions, with solar radiation numbers decreasing by $5.2 \mathrm{~W} \mathrm{~m}^{-2}$ between the third and the second day of data collection, keeping the value of the current assimilated in both days, as well as mean flow data, which remained similar.

The voltage provided by the photovoltaic panel had data always close to $20 \mathrm{~V}$, even with the variations in solar radiation, which, from the first collection at 2:15 pm and $984 \mathrm{~W} \mathrm{~m}^{-2}$ to the fifth collection at 4:00 pm, with a solar radiation of $821 \mathrm{~W} \mathrm{~m}^{-2}$, reached a difference of $163 \mathrm{~W}$ $\mathrm{m}^{-2}$ from the first to the fifth data collection, but always keeping a stable power supply to the water suction pump, as well as a stable flow in each dripper.

It is also observed that in all the tests there was an analogous behavior, with little variability, with respect to the standard deviation, as demonstrated by $\mathrm{CV}$ values, which were below $5 \%$, thus indicating homogeneous data.

The following is the linear regression of the CUC values based on irradiance (Figure 4), in which a small increase in the uniformity coefficients was observed for increasing values of solar irradiance. 
Despite a notable increase in CUC values with increasing irradiance, there is no correlation between the analyzed parameters, since the calculated value of $R^{2}$ is $4.3 \%$, lower than the minimum of $70 \%$ required for statistical correlation between the data, corroborating with the presented values, where, for the first day of collection even with lower values of irradiance, a maintenance in the values of uniformity was observed.

\section{Conclusion}

The results observed in this experiment allow us to conclude that the treatment was considered excellent according to the values of Christiansen's uniformity coefficient (CUC) and the distribution uniformity coefficient (CUD).

Therefore, we recommend the use of the drip irrigation system with electricity supplied by photovoltaic panels connected directly to the water suction pump, on open day days, as carried out in this experiment.

\section{Acknowledgements}

This study was financed in part by the Coordenação de Aperfeiçoamento de Pessoal de Nível Superior - Brasil (CAPES) - Finance Code 001.

\section{References}

American Society of Agricultural and Biological Engineers - Asabe. 1996. Field evaluation of microirrigation Systems. St. Joseph, USA. 792-797p.

Benício, F.R., Carvalho, C.M., Eloi, W.M., Gonçalves, F.M., Borges, F.R.M. 2009. Desempenho de um sistema de irrigação por microaspersão na cultura da goiaba em Barbalha-CE. Revista Brasileira de Agricultura Irrigada 3: 55-61.

Bernardo, S., Soares, A.A., Mantovani, E.C. 2005. Manual de irrigação. UFV, Viçosa, Brasil. 463p.

Christianses, J.E. 1942. Irrigation by sprinkling. University of California, Berkley, USA. 124p.

Costa, J.M., Ortunã M.F., Chaves, M.M. 2007. Deficit irrigation as a strategy to save water: physiology and potential application to horticulture. Journal of Integrative Plant Biology 49: 1421-1434.

Dalri, A.B., Garcia, C.J.B., Zanini, J.R., Faria, R.T.de, Palaretti, L.F. 2015. Caracterização técnica e desempenho hidráulico de quatro gotejadores autocompensantes utilizados no Brasil. Revista
Ciência Rural 45: 1439-1444.

Dillon, A. 2011. Do differences in the scale of irrigation projects generate different impacts on poverty and production? Journal of Agricultural Economics 62: 474-492.

Doun, B., Boujelben, A., Khila, S., Bel Hah Mguidiche, A. 2013. Effect of subsurface drip irrigation system depth on soil water content distribution at different depths and different times after irrigation. Larhyss Journal 13: 7-16.

Ferreira, D.F. 2008. Sisvar: um programa para análises e ensino de estatística. Revista Científica Symposium Lavras 6: 36-41.

Frederiksen, H.D., Allen, R.G. 2011. A common basis for analysis, evaluation and comparison of offstream water uses. Water International 35: 266282.

Gleick, P.H., Christian-Smith, J., Cooley, H. 2011. Water-use efficiency and productivity: rethinking the basin approach. Water International 36: 784798.

Kalogirou, S. 2009. Thermal performance, economic and environmental life cycle analysis of thermosiphon solar water heaters. Solar Energy 83: $39-48$,

Keller, J., Bliesner, R. D. 1990. Sprinkle and trickle irrigation. van Nostrand Reinhold, New York, USA. $652 \mathrm{p}$.

Keller, J., Karmeli, D. 1975. Trickle irrigation design. Rain bird Sprinkler Manufacturing Corporation, Glendora, USA. 133p.

López-Mata, E., Tarjuelo, J.M., Juan, J.A. de Ballesteros, R., Domínguez, R.A. 2010. Effect of irrigation uniformity on the profitability of crops. Agricultural Water Management 98: 190-196.

Mantovani, E.C., Bernardo, S., Palaretti, L.F. 2012. Irrigação: princípios e métodos. UFV, Viçosa, Brasil. $318 \mathrm{p}$

Martins, F.R., Abreu, S. L., Perreira, E.B. 2012. Scenarios for solar thermal energy applications in Brazil. Energy Policy 48: 640-649.

Martins, F.R., Pereira, E.B. 2011. Estudo comparativo da confiabilidade de estimativas de irradiação solar para o sudeste brasileiro obtidas a partir de dados de satélite e por interpolação/ extrapolação de dados de superfície. Revista Brasileira de Geofísica 29: 265-276.

Mauad, F.F., Ferreira, L. da C., Trindade, T.C.G. 2017. Energia Ronavável no Brasil. EESC/ESP São Carlos, Brasil. 348p.

Nascimento, J.M.S. do., Lima, L.A., Cararo, 
D.C., Castro, E.M., Silva, M.V.G. 2009. Avaliação da uniformidade de aplicação de água em um sistema de gotejamento para pequenas propriedades. Revista Ciência e Agrotecnologia 33: $1728-1733$.

Naspolini, H.F., Militão, H.S.G., Rüther, R. 2010. The role and benefits of solar water heating in the energy demands of low-income dwellings in Brazil. Energy Conversion and Management 51: 2835-2845.

Oliveira, L.F.C., Ferreira, R.C., Almeida, R.A., Lobato, E.J.V., Medeiros, A.M.M. 2008. Potencial de redução do consumo de energia elétrica pela utilização de aquecedores solares. Engenharia Agrícola 28: 406-416.

Paulinho, M.A.O., Figueiredo, F.P., Fernandes, R.C., Maia, J.T.L.S., Guilherme, D.O., Barbosa, F.S. 2009. Avaliação da uniformidade e eficiência de água em sistemas de irrigação por aspersão convencional. Revista Brasileira de Agricultura Irrigada 3: 48-54.

Puig-Bargués, J., Arbat, G., Elbana M., DuranRos M., Barragán J., Ramírez de Cartagena F., Lamm F.R. 2010. Effect of flushing frequency on emitter clogging in micro-irrigation with effluents. Agricultural Water Management 7 883-891.

Silva V.P.R, Tavares A.L, Sousa I.F. 2013. Evapotranspiração e coeficientes de cultivo simples e dual do coentro. Revista Horticultura Brasileira 31: 255-259.

Sundata. (2017). Potencial Solar - Sundata. Cresesb/Cepel. Available at: <http://www. cresesb.cepel.br/index.php\#data>. Retrieved: April 2017. 